\title{
COMPARISON BETWEEN EARLY AND LATE DRAIN RELEASED AFTER MODIFIED RADICAL MASTECTOMY SURGERY THROUGH OBSERVATION OVER PROPORTION OF PERCUTANEOUS ASPIRATION TECHNIQUE OF SEROMA PRODUCTION IN SURGICAL POLYCLINIC OF DR. SOETOMO HOSPITAL, SURABAYA
}

\author{
Putra Gelar Parlindungan', Hantoro Ishardyanto ${ }^{2}$ \\ ${ }^{1}$ Surgery Program, ${ }^{2}$ Division of Oncologic Surgery, Department Surgery, Faculty of Medicine, Universitas \\ Airlangga, Dr Soetomo Hospital, Surabaya, Indonesia
}

\begin{abstract}
Surgery is the most frequent indication and major therapy in the management of malignancy of breasts. Drain is one method to drainage the seroma formed after the modified radical mastectomy surgery. The drain-release protocol varies in each hospitals. This study aimed to compare the proportion of percutaneous aspiration in patients with early drain release with late drain release in postoperative MRM patients. The present study is a prospective cohort study comparing the proportion of percutaneous aspiration in 30 patients with early drain released with 30 patients with late drain release in Dr. Soetomo hospital The recording of the proportion of aspiration actions was conducted serially on days 3, 7, 10, and 14 after drain release. Recording of age, nutritional status (BMI), tumor histopathology type, stage, shoulder mobilization time, obliterant usage, wound infections surgery, flap necrosis and hematom were analyzed to find out if there was any effect on seroma event In our study we did not find the difference in serum aspiration proportions both in the early and late drain observation group. Age factor, nutritional status (BMI), histopathology type, stage, shoulder mobilization time, obliterant use, presence of surgical wound infection, flap necrosis and hematom did not differ significantly statistically to seroma events. Statistically, there was no difference in the proportion of percutaneous aspiration in a group of observed patients with early and late drain release. Late drain release can be avoided to potentially harm the patient in decreasing the lives' quality of the patients.
\end{abstract}

Keywords: Drain; early release; late release; seroma

\section{ABSTRAK}

Pembedahan adalah indikasi yang paling sering dan terapi utama dalam penatalaksanaan keganasan payudara. Drainase adalah salah satu metode untuk drainase seroma yang terbentuk setelah operasi mastektomi radikal yang dimodifikasi. Protokol pelepasan drainase bervariasi di setiap rumah sakit. Penelitian ini bertujuan untuk membandingkan proporsi aspirasi perkutan pada pasien dengan pelepasan drainase dini dengan pelepasan drainase lambat pada pasien MRM pasca operasi. Penelitian ini adalah studi kohort prospektif yang membandingkan proporsi aspirasi perkutan pada 30 pasien dengan drainase dini yang dilepaskan dengan 30 pasien dengan drainase lambat di rumah sakit Dr. Soetomo. Pencatatan proporsi tindakan aspirasi dilakukan secara seri pada hari 3, 7, 10, dan 14 setelah rilis drain. Pencatatan usia, status gizi (BMI), jenis histopatologi tumor, stadium, waktu mobilisasi bahu, penggunaan obliter, operasi infeksi luka, flap nekrosis dan hematom dianalisis untuk mengetahui apakah ada efek pada kejadian seroma. Dalam penelitian kami, kami tidak menemukan perbedaan dalam proporsi aspirasi serum baik pada kelompok observasi drainase awal dan akhir. Faktor usia, status gizi (BMI), jenis histopatologi, stadium, waktu mobilisasi bahu, penggunaan obliter, adanya infeksi luka bedah, flek nekrosis dan hematom tidak berbeda secara statistik signifikan dengan kejadian seroma. Secara statistik, tidak ada perbedaan dalam proporsi aspirasi perkutan pada kelompok pasien yang diamati dengan rilis drainase awal dan akhir. Pelepasan saluran yang terlambat dapat dihindari untuk berpotensi membahayakan pasien dalam menurunkan kualitas hidup pasien.

Kata kunci: Drain; keluaran awal; keluaran lambat; seroma

Correspondence: Putra Gelar Parlindungan, Surgery Program, Department of Surgery, Faculty of Medicine, University of Airlangga, Dr Soetomo Hospital, Phone: 081216355669. E-mail: lindungfk@gmail.com

pISSN:2355-8393 • eISSN: 2599-056x • doi: 10.20473/fmi.v56i1.18447

- Fol Med Indones. 2020;56:24-30 • Received 22 Jan $2018 \bullet$ Accepted 19 Jul 2018

- Open access under CC-BY-NC-SA license • Available at https://e-journal.unair.ac.id/FMI/ 


\section{INTRODUCTION}

Women Breast cancer has a high mortality rate in both developed and developing countries and causes very important health problems (Hitti 2007). WHO has data in 2008 that mentioned 480,000 people died from breast cancer. Data from the American Cancer Society in 2007 found that breast cancer was ranked first among most malignancies in women, above the cervical cancer and is the leading cause of death from malignant disease for women in the world. The incidence of breast cancer based on hospital information system data in 2007 reached 8,227 cases (Hitti 2007). Data at Dr. Soetomo hospital obtained 386 new cases in 2010 and ranked second as the most malignant in women after cervical cancer.

Surgery is the most frequent indication and major therapy in the management of malignancy of the breast. Postoperative complications of breast cancer can be found in several forms, including 10\% hematoma, seroma and wound infection surgery by $20 \%, 9 \%$ brachial plexus lesion and flap necrosis (Henrique 2012). Complications of the formation of seroma are a common complication. Seroma incidence is predicted around $10-51 \%$ in all breast surgery cases. (McCaul 2000, Ezeome et al 2008)

Several methods are offered to prevent the occurrence of seroma such as by the action of axillary dissection is good, the use of good surgical instrument, the action of external compression, flap fixation action, the use of dead space obliterance, tissue glue and drain (Dong he 2011) Drain is a method to drain seroma which may form postoperatively modified radical mastectomy (MRM). Negative drainage (closed suction wound drainage) has been widely accepted by many surgeons to reduce morbidity to patients (Theunissen 2001). The occurrence of MRM postoperative sera without drainage of $97 \%$, drained and released on day two of the risk of seroma by $86 \%$, and if maintained over 10 days seroma risk decreased up to $73 \%$ (Talbot 2008).

Until now, the protocol for the release of drain varies in every hospital. Delay of drain release may increase patient duration. Most patients refuse to go home with the drain still in place, causing the patient to feel unsure of properly treating the drain when at home. This will certainly potentially increase the incidence of infection. This is in line with studies that prove the incidence of retrograde infection in drain use (Parikh 1992). The early release of the drain may reduce the length of hospitalization but increase the risk of seroma. If so then it takes repeated serum aspiration and may require surgery to evacuate the seroma. These conditions further increase the risk of infection, flap necrosis, increased length of hospitalization, delay in the implementation of chemotherapy or radiotherapy (Sajid 2013).

The selection of drain types, the number of drains to be installed, the position of the drain installation, the selection of active drain or passive drain with deficiencies and their respective advantages are still controversial (Okada, 2013; Sajid, 2013). There is a lot of controversy about using drain to reduce the incidence of seroma than if it is not attached with drain.(Barton 2006, Okada 2013). Meanwhile, prolonged use of the drain causes an increase in hospital length and the risk of infection due to retrograde germicidal migration. Drain is generally maintained until the production is considered safe after removal, i.e., 30-50 cc per day (McCaul 2000) Drain often maintained until going home considerably reduce the length of hospitalization. (Parikh 1992, Barton 2006)

The use of drain is the two sides of the blade. The early release of the drain potentially leads to sera formation in patients post MRM surgery. Prolonged drainage may result in wound infection due to ascending infection (Parikh 1992, Xue 2012). The condition of surgical wound infections leads to an increase in service cost in cases of breast surgery. The condition occurs because of the increase in patient care time, thus causing the use of hospital resources to be not optimal. Visits to doctors are on the rise, surgical evaluation of surgery needs to be more frequent and in some cases homecare is required. The final conclusion is that the total cost of treatment is getting bigger (Sajid 2013). Another impact that occurs when improper drain release decisions are sera complications and the potential for wound infection. Infection causes delayed radiation and postoperative MRM chemotherapy in some patients, potentially reducing disease free survival.(Jane, 2014) Psychically use of drain is too long will decrease the quality of life of patients. Disruption of daily living activity in some patients and decreased work productivity is one of the effects of drainage is too long (Sajid 2013, Thomson 2013). Considering of the absence of significant benefits and 
the amount of losses suffered by patients due to the length of MRM drainage after surgery, and there is no research to assess the old standard of drainage in postoperative MRM cases in Dr. Soetomo hospital, the authors will examine the proportion of percutaneous percutaneous action on early drain release and slow drain release, with the expectation that if there is no difference, slow release of the drain may be considered to be avoided.

\section{MATERIALS AND METHODS}

This type of research is observational analytic research. The research design used in this study is a prospective cohort. Through this study design, researchers observed and recorded the proportion of percutaneous aspiration action in series, on days 3,7 , 10 , and 14 after the day of drain release in postmodel modified radical mastectomy mammae carcinoma patients. There is a long variation in the release of post modified radical mastectomy for each patient, according to the clinician's assessment in surgical polyclinic at Dr. Soetomo Hospital. Drain will be released by the clinician if it is considered that the drain production has been minimal $(30-50 \mathrm{cc})$. The investigators then assessed the difference in the proportion of percutaneous aspiration actions in patients with early drainage and those who experienced late drainage in postoperative patients modified radical mastectomy. The basic characteristic data subjects were analyzed one by one using statistical tests according to their respective data scales, since there were two in the baseline data using the T-2 free sample scale (if the data ratio is normally distributed) or the Mann-Whitney test (if the data ratio is not normally distributed). For basic data with ordinal data scale using Mann-Whitney test and nominal data scale using chi-square test. Each of the baseline data was analyzed in each observation group and assessed whether the difference was significant or not.

The dependent variable data, in this case the proportion of percutaneous percutaneous acts which is the nominal data, was analyzed using the chi-quare statistical test. If there are significant confounding variables in the observation group then adjustment is made.

\section{RESULTS}

This was observational analytic research. The study design was a prospective cohort. The authors compared the proportion of percutaneous action on post-MRM patient observation of early drain release group with the slow release drain group. Drain release was performed on all post-MRM patients if drain production within 24 hours $\geq 30-50 \mathrm{cc}$. The researchers grouped patients in the early drain-release observation group when the drain was removed on day 7 post MRM. Patients enter the drain-releasing group slow if drain has been removed on the 8th day until the 14th day post MRM. Observations were made on days $3,7,10$, and 14 after drain release. All the drain-releasing measures are performed by a doctor on duty on the oncology surgery polyclinic. Dr. Soetomo Hospital. The independent variable in this research is the time of drain release. The dependent variable on this study is the proportion of percutaneous aspiration action. Confounding variables in this study were BMI, shoulder mobilization time, obliteran use, age of study subjects, surgical wound infection, neoadjuvant therapy, stage of mamae carcinoma, necrosis flap and hematoma.

\section{Sex}

The sex distribution of the study sample was $100 \%$ female. Table 1 shows that the whole sample of research is women in accordance with inclusion criteria established when research is implemented.

\section{Age}

In the early drain observation group, the patient's lowest age was 32 years and the patient's highest age was 64 years with an average age of 49.97 years. The lowest age in the slow drain discharge group was 31 years and the highest age was 63 years with an average age of 50.8 years. The statistically age in the two groups of observations did not differ significantly with the $\mathrm{p}$ value of 0.674 .

\section{BMI}

The nutritional status of the sample in this study was represented by BMI. The BMI distribution in both groups of observations did not differ statistically with significance $(p)$ of 0.662 . 


\section{Shoulder mobilization time}

The time of shoulder mobilization is analyzed as a confounding variable because, according to the literature, shoulder mobilization affects the incidence of sera formation. In each observation group, all patients experienced rapid shoulder mobilization.

\section{Obliteran}

Obliteran was analyzed as confounding variable because of the literature, obliteran have an effect on the occurrence of seroma formation. In each observation group, none was getting obliteran.

\section{Surgery wound infection}

The incidence of wound infection was analyzed as a confounding variable because, according to the literature, wound infections affect the incidence of sera formation. In each of the observation groups, the patient did not have an infection of the surgical wound.

\section{Neoadjuvant chemotherapy}

Neoadjuvant chemotherapy was analyzed as confounding variables because based on the literature, it is known that there is an effect of chemotherapy on the incidence of seroma formation. In observation of drain group released slowly, $73.33 \%$ received neoadjuvant chemotherapy therapy, and $56.6 \%$ observation group released early drain.

\section{Carcinoma mammae stage}

The incidence of wound infection was analyzed as confounding variable because based on the literature it is known that there is influence of chemotherapy on the occurrence of seroma formation. At the observation of drain group released slowly known $73,33 \%$ get neoadjuvant chemotherapy therapy and $56,6 \%$ observation group released early drain. Our data are presented in table 1 .

\section{Flap necrosis}

The incidence of flap necrosis was analyzed as confounding variables because of the corresponding literature, flap necrosis had an effect on the incidence of sera formation. In each observation group no flap necrosis was obtained.

\section{Hematom genesis}

The incidence of hematoma was analyzed as confounding variable because according to the literature, hematoma had an effect on the occurrence of seroma formation. In each observation group, the patient did not experience hematoma.

\section{Proportion of percutaneous aspiration technique in each observation group}

Results of observations in both groups of observations conducted regularly on the third day, seven, ten and fourteen post-drain removed did not get the formation of seroma. Our data are presented in Table 2.

\section{DISCUSSION}

Seroma is a complication of the most frequent breast surgery. Seroma is the accumulation of serous fluid in the dead space area after mastectomy surgery where one of the procedures is a breast skin flap. Serogenic pathogenesis has not been fully explained. but seroma has the potential to cause post-MRM problems such as delayed wound healing, flap necrosis, wound dehiscence of surgery which then causes delay in adjuvant treatment. Factors that are considered responsible for seroma formation in general can be divided based on patient factors, surgical factors, drain use, obliteran use and shoulder mobilization. Drain is a factor that is considered most responsible for the incidence of seroma because it plays a role in evacuating the formation of seroma so that wound healing can work well.

Our results showed that there was no significant difference in percutaneous percutaneous action in the early-released drain group with the slow-release drain group. These results supported the researcher's hypothesis that the release of the old drain can be avoided so as to reduce complications due to ascending infection, minimizing the discomfort of patients due to the drainage taking too long and globally can lower the total cost of patient care.

The study looked at new standards related to the post MRM drain release criteria. In the control group was released according to the procedure where the volume per 24 hours $50 \mathrm{cc}$ and in the intervention group was released on the fifth day regardless of the volume recorded per 24 hours. It is known that 
although there is no difference in the formation of sera after the release of drain. Apparently it is necessary to visit the clinic more often when drain is released on the fifth day regardless of volume in 24 hours (Okada 2013). This is in line with our study that the volume per 24 hours needs to remain a concern. Thus, the need for percutaneous aspirations can be minimized.

The results of this study support previous studies that compared the use of drain and without drain in patients with post-radical breast carcinoma mastectomy. The study involved 261 patients with postoperative drain installation and 335 patients without drain. The study found that there were no differences in both groups, either on the number of serum formations, percutaneous aspiration measures, surgical wound infection rates and complications. The use of drain was associated with long hospital length with significance value $(P<0.001)$. in the study did not display the basic demographic characteristics of patients between the two groups compared so it is difficult to draw conclusions from the search. In the study the researchers removed the drain when the drain volume was $50 \mathrm{ml}$ in 24 hours on day 7. In our study, the drain was released when the volume had reached $30 \mathrm{ml}$. Thus, our research with this study cannot be compared fully.

Table 1. Characteristics of research data

\begin{tabular}{|c|c|c|c|c|}
\hline \multicolumn{2}{|c|}{ Sample Characteristics } & $\begin{array}{l}\text { Early drain release } \\
\text { group } \\
\mathrm{n}=30\end{array}$ & $\begin{array}{l}\text { Late drain release group } \\
\qquad \mathrm{n}=30\end{array}$ & Significance \\
\hline \multicolumn{2}{|c|}{ Age , Mean \pm SD (year) } & $49.97 \pm 7.613$ & $50.8 \pm 7.672$ & 0.674 \\
\hline \multirow[t]{4}{*}{ BMI } & Normal & $50 \%(15)$ & $40 \%(12)$ & 0.662 \\
\hline & Overweight & $30 \%(9)$ & $46.7 \%(14)$ & \\
\hline & Obese & $6.7 \%(2)$ & $13.3 \%(4)$ & \\
\hline & Severely obese & $13.3 \%(4)$ & $0.0 \%(0)$ & \\
\hline \multirow{2}{*}{$\begin{array}{c}\text { Time of shoulder } \\
\text { mobilization }\end{array}$} & Fast & $100 \%(30)$ & $100 \%(30)$ & \\
\hline & Slow & $0 \%(0)$ & $0 \%(0)$ & \\
\hline \multicolumn{2}{|c|}{ Obliteran } & 0 & 0 & \\
\hline \multicolumn{2}{|c|}{ Surgery wound infection } & 0 & 0 & \\
\hline \multirow{2}{*}{$\begin{array}{l}\text { Neoadjuvant } \\
\text { chemotherapy }\end{array}$} & Yes & $56.67 \%(17)$ & $73.33 \%(22)$ & 0.279 \\
\hline & No & $43.4 \%(13)$ & $26.67 \%(8)$ & \\
\hline \multirow{3}{*}{$\begin{array}{c}\text { Carcinoma } \\
\text { mammae stage }\end{array}$} & Stage 1 & $10 \%(3)$ & $6.67 \%(2)$ & 0.545 \\
\hline & Stage 2 & $36.67 \%(11)$ & $53.33 \%(16)$ & \\
\hline & Stage 3 & $53.33 \%(16)$ & $40 \%(12)$ & \\
\hline Flap & Yes & $0 \%(0)$ & $0 \%(0)$ & \\
\hline Necrosis & No & $100 \%(30)$ & $100 \%(30)$ & \\
\hline Hematom & Yes & $0 \%(0)$ & $0 \%(0)$ & \\
\hline Genesis & No & $100 \%(30)$ & $100 \%(30)$ & \\
\hline
\end{tabular}

Table 2. Percutaneous aspiration proportion

\begin{tabular}{ccccccccc}
\hline & \multicolumn{9}{c}{ Observation day after drain release } \\
\cline { 2 - 9 } $\begin{array}{c}\text { Percutaneous } \\
\text { Aspiration } \\
\text { Actions }\end{array}$ & $\begin{array}{c}\text { Early } \\
\text { release } \\
\text { drain }\end{array}$ & $\begin{array}{c}\text { Late } \\
\text { release } \\
\text { drain }\end{array}$ & $\begin{array}{c}\text { Early } \\
\text { release } \\
\text { drain }\end{array}$ & $\begin{array}{c}\text { Late release } \\
\text { drain }\end{array}$ & $\begin{array}{c}\text { Early } \\
\text { release } \\
\text { drain }\end{array}$ & $\begin{array}{c}\text { Late release } \\
\text { drain }\end{array}$ & $\begin{array}{c}\text { Early } \\
\text { release } \\
\text { drain }\end{array}$ & $\begin{array}{c}\text { Late } \\
\text { release } \\
\text { drain }\end{array}$ \\
\hline Positive(+) & 0 & 0 & 0 & 0 & 0 & 0 & 0 & 0 \\
Negative(-) & 30 & 30 & 30 & 30 & 30 & 30 & 30 & 30 \\
\hline
\end{tabular}


Research in the next year in 2014 involved the analysis of more complete demographic data. The study also compared a group of post-radical mastectomy patients who used drain to patients with no drain. Researchers looked at retrospectively as many as 96 breast carcinoma patients and compared seroma production in patients who used post-MRM drain and who did not use post MRM drain. In the study there was no difference of frequency of seroma formation among groups using drain (84.6\%) while group did not use drain $(90.9 \%)$ with $p$ value: 0.290 and seroma volume in group that did not use drain $(540)$ and use drain $(590 \mathrm{ml})$ with $\mathrm{p}$ value: 0.446 . The length of postoperative care was also shorter in patients without drain (of 2) compared with those using drain (2.5) with $\mathrm{p}=0.003$ ). The study also showed no significant differences in secondary outcomes such as bleeding, surgical wound infections, gastrointestinal symptoms, cardiovascular symptoms, respiratory symptoms, neurological symptoms, psychic symptoms and potential reoperative measures. This study demonstrated the demographic characteristics of the data clearly and stated that MRM is an independent predictor factor for the number of postoperative seroma (HR 0.039 [0.007-0.235], $\mathrm{p}<0.001)$. (39) In this study, patients using drain were routinely released on the first day of postoperative, while in our study, drain removed if drain production has been less than $30 \mathrm{cc}$, so our study also cannot be compared with the research.

Systematic reviews show results contrary to our research results and the two studies we mentioned above. The study analyzed as many as 6 RCTs showed that drain insertion was statistically significant in reducing seroma formation, serum aspirate volume and there was no difference in incidence of wound infection. However, the quality of 4 of the 6 RCTs remains to be questioned. In these studies, no clear number of samples was analyzed. The number of samples is relatively smaller (20-119) and there is a difference in the definition among the studies (Guo 2011).

\section{CONCLUSION}

Installation of drain in Indonesia is still the main choice to prevent the formation of post MRM seroma. The criteria for drain discharges are still debatable, whether based on drain volumes or time. Our study makes clear that only one guideline is used to remove drain in post-MRM patients, i.e., the drain volume is less than $50 \mathrm{cc}$. This study makes it clear that clinicians in the surgical clinic do not have to hesitate to remove the drain if the drain volume meets the criteria, even if the patient arrives on the first post-MRM day. This is consistent with our research data, that there is no difference in percutaneous percutaneous perceptions on the 3rd, 7th, 10th and 14th day observations in each of the early drain observation groups and the drain observation group is released slowly.

\section{REFERENCES}

Barton A BM, Callahan D, et al (2006). Early removal of postmastectomy drains is not beneficial: results from a halted randomized controlled trial. The american journal of surgery 191:652-6.

Dong he X GZ, Tian J, et al (2011). Whether drainage should be used after surgery for breast cancer? A systematic review of randomized controlled trials. Medical oncology 28, 22-30

Ezeome R. Adebamowo C, et al (2008). Closed suction drainage versus closed simple drainage in the management of modified radical mastectomy wounds. South African Medical Journal 98, 712-5

Guo, He, Tian, et al (2011). Whether drainage should be used after surgery for breast cancer? a systematic review of randomized controlled trials.. medical Oncology 28, 22

Henrique G ML, Luiz R, et al (2013). Modified radical mastectomy: A pilot clinical trial comparing the use of conventional electric scalpel and harmonic scalpel. International Journal of Surgery $11,496-500$

Hitti M (2007). World Cancer Deaths Top 7 Million. Available at http://www.webmd.com/cancer/news/ 20071217/2007-world-cancer-deaths-top-7million 2007

Jane H, Turner JRB, Zoë E, Winters (2014). Techniques in the prevention and management of seromas after breast surgery. Future Oncology 10, 1049-63

McCaul JA (2000). Aetiology of seroma formation in patients undergoing surgery for breast cancer. The Breast 9,144-8

Okada N NY, Takada M, Kato H, et al (2013). Early removal of Drains and The incidence of Seroma After Breast Surgery. Breast Cancer 2, 1-5

Parikh KBA, et al (1992). Early drain removal following modified radical mastectomy: a 
randomized trial. Journal of surgical oncology 51, 266-9

Sajid MS HK, Rapisarda IF, Bonomi R (2013). Fibrin glue instillation under skin flaps to prevent seromarelated morbidity following breast and axillary surgery (Review). Cochrane Database of Systematic Reviews.

Talbot ML, Magarey CJ (2002). Reduced use of drains following axillary lymphadenectomy for breast cancer. ANZ Journal of Surgery 72, 488-90

Theunissen D CJ, Dent M, et al (2001). Factors that influence volume and duration of wound drainage after mastectomy and level III axillary node clearance. The breast 10, 538-9

Thomson DR, Sadideen H, Furniss D (2013). Wound drainage after axillary dissection for carcinoma of the breast. Cochrane Database of Systematic Reviews.

Xue DQ, Qian C, Yang L, Wang XF (2012). Risk factors for surgical site infections after breast surgery: A systematic review and meta-analysis. European Journal of Surgical Oncology (EJSO) 38, 375-81 